\title{
ANALISIS SWOT UNTUK DIRECT CO-FIRING BATUBARA DENGAN PELLET SAMPAH PADA BOILER TIPE CFBC
}

\author{
Muhammad Fadli $^{1}$, Dianta Mustofa Kamal ${ }^{2}$, Pribadi Mumpuni Adhi ${ }^{2}$ \\ ${ }^{1}$ Program Studi Pembangkit Tenaga Listrik, ${ }^{2}$ Magister Terapan Rekayasa Teknologi Manufaktur, \\ Jurusan Teknik Mesin, Politeknik Negeri Jakarta \\ Jalan Prof. Dr. G. A. Siwabessy, Kampus UI, Depok 16425 \\ e-mail:mfadli2428@gmail.com,dianta@mesin.pnj.ac.id,pribadi.adhi@mesin.pnj.ac.id
}

\begin{abstract}
Indonesia to be the world's second-largest contributor of plastic waste in the oceans. Every resident in Indonesia can produce 0,52 $\mathrm{kg} /$ person/day of waste. Efforts to overcome the problem of waste by processing it into Pellets, which contain calories from 2,800 to $3,300 \mathrm{kcal} / \mathrm{kg}$ using the peuyeumisasi method, so that they can use for co-firing in PLTU. Trial for direct co-firing coal and RDF Pellet from Klungkung Bali, will be carry out on Circulating Fluidized Bed Combustion (CFBC) boiler. The goal of study to analyze the feasibility for co-firing with SWOT analysis. The SWOT analysis questionnaire was compiled based on internal and external factors, which was carried out through the study of literature and document. After the questionnaire was compiled, the questionnaire was given to respondents who collected 10 people, selected based on factors of relevance and understanding of the issues discussed. The results of the questionnaire show the main indicators, which are divided into 2 parts, internal factors consisting of strengths, weaknesses and external factors consisting of opportunities and threats. Then implemented in the SWOT matrix, to get the best strategy and whether the decision is feasible or not. The results is feasible to be implemented in the PLTU MSW, with internal factor value of 3,03 or rounded to 3 (strong) and an external factor value of 2,6 or rounded to 3 (strong). Several strategies are designed to use the strength to take advantage of opportunities, reduce weaknesses and threats.
\end{abstract}

Key words: RDF Pellet, Co-firing, SWOT Analysis

\begin{abstract}
ABSTRAK
Indonesia berada pada peringkat ke dua di dunia penyumbang sampah plastik ke laut. Setiap penduduk di Indonesia dapat menghasilkan sampah sebanyak 0,52 kg/jiwa/hari. Upaya mengatasi permasalahan sampah dengan mengolahnya menjadi Pellet yang mengandung kalori 2800-3300 kcal/kg menggunakan metode peuyeumisasi, sehingga bisa dimanfaatkan PLTU untuk dicampur dengan batubara (co-firing). Uji coba direct co-firing batubara dan Pellet sampah dari Klungkung Bali akan dilakukan pada boiler tipe Circulating Fluidized Bed Combustion (CFBC). Penelitian ini bertujuan menganalisa kelayakan cofiring Pellet sampah dan batubara dengan pendekatan analisis SWOT. Kuesioner analisis SWOT disusun berdasarkan identifikasi faktor internal, dan eksternal yang dalam penelitian ini dilakukan melalui studi pustaka terhadap dokumen dan literatur terkait. Setelah kuesioner disusun, kuesioner diberikan kepada responden yang berjumlah 10 orang, dipilih berdasarkan faktor keterkaitan serta pemahaman terhadap masalah yang diteliti. Hasil kuesioner menunjukkan penilaian terhadap indikator-indikator utama, yang terbagi ke dalam 2 bagian, yaitu : faktor internal berupa strengths (kekuatan), weakness (kelemahan) serta faktor eksternal berupa opportunities (peluang) dan threats (ancaman). Kemudian diimplementasikan dalam matriks SWOT, untuk mendapatkan strategi terbaik serta keputusan layak atau tidaknya. Hasilnya adalah layak diimpelmentasikan pada PLTU MSW, dengan nilai fakot internal 3,03 atau atau dibulatkan menjadi 3 (kuat) dan nilai faktor eksternal 2,6 atau dibulatkan menjadi 3 (kuat). Beberapa strategi disusun agar menggunakan kekuatan untuk memanfaatkan peluang serta memperbaiki kelemahan dan mengurangi ancaman.
\end{abstract}

Kata kunci : Pellet Sampah, Co-firing, Analisis SWOT

\section{PENDAHULUAN}

Salah satu permasalahan sosial yang sering timbul di perkotaan suatu negara adalah permasalahan sampah. Sebuah penelitian menyebutkan, Indonesia berada pada peringkat ke dua di dunia penyumbang sampah plastik ke laut 
setelah Tiongkok, disusul Filipina, Vietnam dan Sri Langka [6]. Diperkirakan setiap penduduk di Indonesia dapat menghasilkan sampah sebanyak 0,52 kg/jiwa/hari [1]. Khusus di Kabupaten Tabalong Provinsi Kalimantan Selatan, jumlah sampah ditimbun TPA periode 2017-2018 adalah 58 ton/hari dengan jumlah sampah tidak terkelola 18,79 ton/hari, sehingga presentase yang tertanggulangi baru 67,6 \% [13].

Upaya untuk mengatasi permasalaha sampah telah dilakukan oleh Pemda Klungkung (Bali) bersama Sekolah Tinggi Teknik (STT) PLN dan Indonesia Power (IP) meluncurkan program Tempat Olah Sampah Setempat (TOSS). Sampah langsung diolah menjadi briket dan Pellet dengan metode peuyeumisasi. Pellet yang berupa bulatan-bulatan kecil mengandung kalori 2500 - $4000 \mathrm{kcal} / \mathrm{kg}$ [9] yang kemudian bisa dimanfaatkan pembangkitan listrik skala besar untuk dicampur dengan batubara.

Pemerintah Kabupaten Tabalong, berencana membuat sistem TOSS seperti di Klungkung. Sampah yang ada dikumpulkan lalu diolah menjadi Pellet. Pellet akan digunakan sebagai campuran bahan bakar batubara PLTU mulut tambang berkapasitas $2 \times 30 \mathrm{MW}$ di Tabalong milik PT. Makmur Sejahtera Wisesa (MSW). PLTU MSW yang menggunakan boiler tipe Circulating Fluidized Bed Combustion (CFBC) akan menjadi PLTU pertama di Kalimantan yang melakukan direct cofiring batubara dengan Pellet sampah. Ujicoba akan dilaksanakan akhir 2019 menggunakan Pellet sampah dari Klungkung (Bali). Oleh karena itu, penelitian ini bertujuan menganalisa kelayakan uji coba co-firing berdasarakan perbandingan batu bara dan Pellet sampah paling optimum serta mengetahui internal strategy factor analysis (IFAS) dan eksternal strategy factor analysis (EFAS) menggunakan pendekatan analisis SWOT.

Pemanfaatan sampah sebagai bahan bakar disebut Refused Derived Fuel (RDF) [16]. Salah satu sumber sampah untuk menghasilkan RDF berasal dari MSW (Municipal Solid Waste) atau sampah kota [5]. Berdasarkan standar ASTM E856-83 (American Standard Testing and Material), terdapat 7 tipe RDF yang diklasifikasikan sesuai dengan wujud dan proses pemilahan awalnya. Pengklasifikasian RDF di Eropa diatur oleh UNI CEN/TS 15359 berdasarkan tiga sifat bahan bakar, yaitu net calorific value berfungsi sebagai indikator ekonomi, kandungan klorin sebagai indikator teknologi dan kandungan merkuri sebagai parameter lingkungan [16]. Pengklasifikasian bertujuan menentukan secara rinci sifat kimia dan fisikanya yang menjamin dari penyalahgunaan ketika bahan bakar dari sampah ini diperjualbelikan seperti batubara.

Kandungan klorin pada RDF dapat dipisahkan sebagai klorin organik (misal PVC) dan klorin anorganik (misal $\mathrm{NaCl}$ ). Ketika pembakaran RDF, kandungan klorinnya dalam furnace bereaksi sebagai uap asam klorida atau klorida yang mengembun di permukaan furnace seperti garam dan menyebabkan korosi [18]. HCl juga dapat bereaksi dengan molekul organik sehingga membentuk dioksin dan furan. Mekanisme tersebut ditampilkan pada gambar 1. Kandungan klorin dalam deposit mempercepat proses korosi dengan menurunkan softening temperature (ST) yang ketika meleleh dapat merusak lapisan oksida permukaan logam. Oleh karena itu, ketika temperatur deposit lebih tinggi dari ST, kecepatan korosi meningkat secara signifikan. Telah ditetapkan bahwa ketika rasio molar $\mathrm{S} / \mathrm{Cl}$ lebih dari 4, bahan bakar dapat dianggap sebagai non-korosif. Jika S/Cl kurang dari 2, bahan bakar bersifat korosif [10]. 
Dioksin (PCDD) dan furan (PCDF) merupakan produk sampingan yang secara tidak sengaja terjadi dalam proses pembakaran. Pembakaran yang mengandung bahan klorin, seperti plastik PVC akan meningkatkan produksi dioksin dan furan [17]. Temperatur optimum untuk pembentukan dioksin dan furan adalah 250- $400^{\circ} \mathrm{C}$ [7]. Dampak pencemaran dioksin dan furan terhadap kesehatan untuk jangka panjang adalah kanker, gangguan pada sistem reproduksi dan cacat lahir.

Co-firing adalah proses pembakaran dua material yang berbeda secara bersamaan, sering diaplikasikan pada batubara dan biomassa dengan cara substitusi sebagian batubara dengan biomassa ke dalam unit pembangkit. Keuntungan co-firing adalah terjadinya pengurangan gas $\mathrm{CO}_{2}$, SOx dan NOx pada bahan bakar fosil, karena biomassa dikenal sebagai zero $\mathrm{CO}_{2}$ sehingga tidak menyebabkan akumulasi $\mathrm{CO}_{2}$ di atmosfer dan mengandung lebih sedikit sulfur jika dibanding batubara [19].

Berdasarkan penelitian ERFO-

European Recovered Fuel Organisation : “SRF Markets" Maret 2006, setiap 1 ton RDF (melalui produksinya dari MSW dan co-firing) bisa mengurangi emisi CO2 sebesar 1,75 ton/ $\mathrm{CO}_{2}[20]$.

Terdapat 3 potensi masalah dari cofiring Pellet sampah dan batubara, yaitu korosi pada tube perpindahan panas, kualitas ash, dan emisi yang dihasilkan [10]. Co-firing dengan menggunakan 5\% Pellet sampah berpotensi meningkatkan laju pembentukan deposit [8].

Pada 2009, PLTU batubara Italia yang berlokasi di Fusina-Venice milik ENEL “Andrea Palladio" kapasitas 320 MW unit 4, telah sukses melakukan co-firing dengan perbandingan 95\% batubara bituminus dan 5\% Pellet sampah menghasilkan emisi yang rendah serta efisiensi termal hingga 35\%. Pellet sampah yang dibutuhkan adalah 6,7 t/h.
Saat ini sekitar $70 \mathrm{kt} / \mathrm{y}$ Pellet sampah dikirim ke ENEL, tetapi diharapkan meningkat menjadi 100-105 kt/y. Setiap 1 ton Pellet sampah yang digunakan untuk co-firing dapat menghindari produksi $500 \mathrm{~kg} \mathrm{CO}_{2}$ [20]. Pellet sampah yang diproduksi memiliki ratarata nilai kalor $4300 \mathrm{kcal} / \mathrm{kg}$, kandungan klorin 0,92\% dan kandungan merkuri 0,024 mg/MJ [3]. Perihal korosi sudah dilakukan pemantauan 8-15 bulan di ruang bakar dan superheater. Hasilnya korosi dapat diabaikan pada superheater dengan material baja S304H dan 347H. Pada dinding ruang bakar menunjukkan bahwa terjadi korosi dekat nozzel RDF dengan material baja 16Mo3 dan A105 [4].

Pada 1998 dan 1999, Korea Electric Power Corporation (KEPCO) membangun PLTU Donghae (Korea Selatan) yang menggunakan boiler tipe CFBC dengan kapasitas 2×200 MW. PLTU menggunakan batubara jenis antrasit dengan kandungan ash yang tinggi dan volatile matter (VM) rendah. Hal tersebut membuat reaktivitas batubara antrasit menjadi rendah, sehingga efisiensi pembakaran rendah, operasi boiler menjadi tidak stabil dan produksi listrik yang terbatas karena pembatasan supply, produksi dan harga bahan bakar yang mahal. Untuk mengatasi hal tersebut, PLTU Donghae berinovasi melakukan co-firing batubara dengan Pellet sampah yang dikenal memiliki nilai VM tinggi, dengan perbandingan 1-5\% Pellet sampah. Pellet sampah yang dibutuhkan adalah 4,2 t/h. Hasilnya adalah tidak ada perubahan signifikan pada temperatur, tekanan dan emisi sebelum maupun setelah co-firing[7]. Temperatur meningkat sedikit pada sisi bawah dan outlet furnace, karena Pellet sampah mengandung VM yang tinggi dan reaktivitas pembakaran yang cepat di furnace sisi bawah dibandingkan batubara antrasit. Tekanan pada furnace sisi atas juga menurun sedikit, karena 
adanya perbedaan ukuran Pellet sampah (15-50 mm) dengan batubara antrasit $(<6 \mathrm{~mm})$. Tetapi hal tersebut tidak mengganggu kestabilan operasi. Untuk emisi dioksin dan furan, kadarnya masih di bawah ambang batas yang ditetapkan pemerintah Korea Selatan, sedangkan emisi NOx dan SOx menurun sedikit, karena kandungan Pellet sampah relatif memiliki kandungan S, $\mathrm{N}$ yang lebih kecil dibandingkan batubara antrasit. Kandungan HCL meningkat sedikit, karena klorin pada Pellet sampah lebih besar dibandingkan batubara antrasit Di Indonesia, uji coba pertama co-firing Pellet sampah (RDF) dan batubara baru saja dilakukan PLTU Jeranjang Nusa Tenggara Barat milik PT Indonesia Power pada 19-20 Februari 2019. Pellet sampah yang berasal dari Klungkung Bali digunakan sampai dengan 5\% dari kebutuhan bahan bakar PLTU Jeranjang yang menggunakan boiler tipe CFBC. Uji coba dilakukan pada beban 25 MW dengan tahapan hari pertama uji operasional dan hari kedua uji stabilitas selama 5 jam. Hasil uji coba menunjukan hasil yang positif dimana sebagian besar parameter operasi dalam batas aman dan emisi gas buang yang didapat juga dalam batas normal. Komposisi Pellet sampah sendiri terbuat dari campuran sampah organik dan anorganik (non PVC) dengan perbandingan 95\% : 5\%. Pellet sampah dilakukan analisa proximate maupun ultimate untuk mengetahui Ash Fusion Temperature (AFT) dan memastikan seberapa besar risiko slagging akibat penggunaan pellet sampah. Hasilnya, AFT pada $1344{ }^{\circ} \mathrm{C}$ yang menunjukkan potensi slagging cenderung rendah [15]. Pellet sampah Klungkung Bali berasal dari sampah kota yang dibuat dengan metode peuyeumisasi. Metode ini ditemukan dan dikembangkan oleh Sonny Djatnika Sundadjaya [17]. Proses tersebut bisa dibuat dalam waktu kurang dari 10 hari. Peuyeumisasi merupakan proses alami menggunakan keramba bambu, mengkonversi sampah organik dan anorganik menjadi bahan bakar padat melalui proses pemeraman secara mikrobiologi yang bertujuan mempercepat terjadinya peluruhan/penguraian (degradasi) sampah padat. Metode ilmiah yang digunakan adalah dengan memanfaatkan bioactivator berisi bakteri tertentu sehingga sampah tersebut bisa hilang baunya dan menyusut serta menghasilkan suatu produk briket sampah lalu dicetak menjadi Pellet dengan diameter $10 \mathrm{~mm}$ - 12 mm yang memiliki kadar kalori 2500 - $4000 \mathrm{kcal} / \mathrm{kg}$ [9].

\section{METODE PENELITIAN}

Wawancara meliputi kegiatan diskusi dan tanya-jawab dengan power plant manager, plant performance section head, operation section head, serta operator distribution control system (DCS) dan expert. Kemudian pengumpulan data proximate dan ultimate analysis Pellet sampah Klungkung Bali dari Sumitomo Heavy Industries, LTD (Jepang). Hasil proximate \& ultimate analysis Pellet sampah Klungkung Bali, dilakukan studi kelayakan untuk direct co-firing dengan batubara di PLTU berdasarkan jurnal penelitan, dan best practice dari PLTU yang sudah melakukannya. Kuesioner analisis SWOT disusun berdasarkan identifikasi faktor internal, dan eksternal yang dalam penelitian ini dilakukan melalui studi pustaka terhadap dokumen dan literatur terkait. Setelah kuesioner disusun, kuesioner diberikan kepada responden yang berjumlah 10 orang, dipilih berdasarkan faktor keterkaitan serta pemahaman terhadap masalah yang diteliti (purposive sampling). Berdasarkan hasil kuesioner, didapatkan penilaian terhadap indikator-indikator utama yang terbagi ke dalam 2 bagian, yaitu : faktor 
internal berupa strengths (kekuatan), weakness (kelemahan) dan faktor eksternal berupa opportunities (peluang) dan threats (ancaman) [11]. Kemudian diimplementasikan dalam matriks SWOT, untuk mendapatkan strategi terbaik serta keputusan layak atau tidaknya implementasi direct cofiring Pellet sampah dengan batubara di PLTU MSW.

Untuk menjaga keberlanjutan co-firing PLTU MSW dari permasalahan jumlah dan kapasitas peralatan pengolahan sampah yang kurang (keramba bambu, mesin pencacah, mesin pencetak Pellet dll.) dibandingkan jumlah sampah yang masuk. Co-firing dilaksanakan 3 jam setiap harinya ketika beban penuh (28 MW) yang biasanya pada siang hari, misal dari jam 11.00 WITA hingga jam 14.00 WITA. Kebutuhan rata-rata batubara PLTU MSW jika beban 28 MW adalah $20 \mathrm{t} / \mathrm{h}$. Jika co-firing dilakukan dengan perbandingan 95\% batubara : 5\% Pellet sampah (seperti PLTU Jeranjang, PLTU Andrea Palladio Italia dan PLTU Donghae Korea Selatan), maka 5\% dari $20 \mathrm{t} / \mathrm{h}$ adalah $1 \mathrm{t} / \mathrm{h}$ Pellet sampah. Jadi, kebutuhan Pellet sampahnya adalah 3 ton per hari.

\section{HASIL DAN PEMBAHASAN}

Berdasarkan standar ASTM E856-83, Pellet sampah Klungkung Bali berkode RDF-5, yaitu limbah yang dapat dibakar (combustible) kemudian dipadatkan menjadi bentuk Pellet atau briquettes (densified RDF).

Tabel 1 menampilkan perbandingan Pellet sampah Bali, Pellet sampah Korea Selatan dan Pellet sampah Italia. Berdasarkan klasifikasi RDF UNI CEN/TS 15359, Pellet sampah Bali untuk NCV berada di kelas 4, klorin di kelas 4, sedangkan merkuri tidak ada hasil uji laboratoriumnya (analisa proximate dan ultimate selanjutnya harus mengukur kandungan merkuri juga pada Pellet sampah Bali). Pellet sampah Korea Selatan untuk NCV di kelas 3, klorin di kelas 3 dan merkuri tidak ditemukan datanya, sedangkan Pellet sampah Italia untuk NCV berada di kelas 3, klorin di kelas 3, dan merkuri di kelas 2. Hasil penentuan kelas tersebut, menunjukkan bahwa Pellet sampah Korea Selatan dan Italia lebih baik kandungannya dari segi indikator ekonomi (NCV), indikator teknologi (klorin) dan lingkungan (merkuri).

Kandungan klorin pada Pellet sampah Bali lebih besar 0,3 \% dari Pellet sampah Korea Selatan dan 0,18 \% dari Pellet sampah Italia serta kandungan ash juga lebih banyak, sehingga kemungkinan terjadi korosi lebih tinggi. Berdasarkan rasio molar $\mathrm{S} / \mathrm{Cl}$, Pellet sampah Bali dan Korea Selatan bersifat korosif, karena hasil perbandingannya kurang dari 2. Untuk Pellet sampah Italia korosif atau tidak, karena data sulfur tidak ditemukan dan biomassa dikenal dengan sulfur yang rendah, bisa diasumsikan juga rasio molar $\mathrm{S} / \mathrm{Cl}$ pada Pellet sampah Italia kurang dari 2 juga (bersifat korosif).

Korosi merupakan proses alam yang tidak dapat dihindari namun dapat dicegah atau diminimalisir. Pemantauan korosi selama 8-15 bulan di PLTU Batubara Italia milik ENEL yang sudah menggunakan co-firing dengan Pellet sampah telah dilakukan.

Hasilnya menujukkan terjadi korosi pada dinding ruang bakar dekat nozzel Pellet sampah, tetapi efisiensi termal tetap dapat dipertahankan hingga 35\% serta menghasilkan emisi yang rendah. Selanjutnya digunakan sistem pemantauan korosi RSE (Ricerca Sistema Energetico) yang dapat menunjukkan pengukuran degradasi material akibat korosi secara on-line serta tepat waktu kepada plant managers dalam berbagai kondisi operasi yang berguna untuk optimasi sesuai dengan pemeriksaan metalografi. Selain itu, upaya untuk meminimalisir 
terjadinya korosi adalah optimasi pengoperasian soot blower dan sudah adanya perkembangan terbaru perlindungan korosi, melapisi pipa dengan lapisan porositas keramik kadar di bawah $1 \%$ untuk menghindari kontak antara chlorine dan logam dengan tebal lapisan sekitar 75-90 $\mu \mathrm{m}$ [2].

Skala penilaian untuk faktor positif (kekuatan dan peluang) sebagai berikut : 1 untuk nilai sangat lemah, 2 untuk nilai lemah, 3 untuk nilai kuat dan 4 untuk nilai sangat kuat. Sedangkan untuk menilai faktor negatif (kelemahan dan ancaman) digunakan skala dengan pola sebagai berikut : 1 untuk nilai sangat kuat, 2 untuk nilai kuat, 3 untuk nilai lemah, dan 4 untuk nilai sangat lemah. Nilai bobot ditentukan dari hasil kuesioner yang diberikan kepada responden. Untuk mempermudah pemberian nilai skor dan bobot, digunakan tabel internal strategy factor analysis (IFAS) dan eksternal strategy factor analysis (EFAS), seperti pada tabel 2 dan 3.

Berdasarkan tabel 3 dan tabel 4, diketahui bahwa nilai faktor internal 3,03 atau dibulatkan menjadi 3 (kuat). Sedangkan nilai faktor eksternalnya 2,6 atau dibulatkan satu digit menjadi 3 (kuat). Kemudian untuk merumuskan strategi pengembangan, penulis menggunakan diagram bantu seperti pada Gambar 3.

Karena nilai IFAS dan EFAS adalah 3, maka dengan alat bantu diagram di atas dipilihlah strategi yang menggunakan kekuatan untuk memanfaatkan peluang atau Strength-Opportuinity (SO). Adapun strategi SO yang dapat dilakukan pada direct co-firing Pellet sampah dan batubara di PLTU MSW adalah sebagai berikut :

1. Sosialisasi dan promosi program direct co-firing ke Kementerian Energi Sumber Daya Mineral dan Kementerian Lingkungan Hidup untuk mendukung program tersebut dalam hal peraturan, kemudahan akses dll.

2. Segera melakukan pilot project TOSS (Tempat Olah Sampah Setempat) bersama Pemerintah Daerah Kabupaten Tabalong (lokasi PLTU MSW) untuk memanfaatkan sumber energi lokal berupa sampah kota menjadi Pellet sampah dengan metode peuyeumisasi dan memberdayakan masyarakat pada setiap TPS/TPA sebagai petugas TOSS.

Selain itu, penulis menambahkan beberapa strategi untuk memperbaiki kelemahan serta mengurangi ancaman :

1. Melakukan uji laboratorium ulang terhadap fly ash setelah direct cofiring Pellet sampah dan batubara, kemudian memberikan hasil ujinya kepada pabrik semen yang biasa mengambil fly ash PLTU MSW.

2. Sosialisasi dan pelatihan kepada warga sekitar TPS/TPA yang akan menjadi petugas pengolah Pellet sampah tentang jenis sampah organik, anorganik, dan sampah yang mengandung klorin.

3. Studi dan kunjungan ke PLTU Jeranjang ketika shutdown untuk melihat kondisi ruang bakar, jalur konveksi (supeheater), serta ash setelah melakukan co-firing Pellet sampah dan batubara.

4. Untuk menjaga keberlanjutan cofiring PLTU MSW dari permasalahan jumlah dan kapasitas peralatan pengolahan sampah yang kurang (keramba bambu, mesin pencacah, mesin pencetak Pellet dan lain-lain) dibandingkan jumlah sampah yang masuk. Co-firing dilaksanakan 3 jam setiap harinya ketika beban penuh (28 MW) yang biasanya pada siang hari, misal dari jam 11.00 WITA hingga jam 14.00 WITA. Kebutuhan rata-rata batubara PLTU MSW jika beban 28 MW adalah 20 t/h. Jika co-firing dilakukan dengan perbandingan 95\% 
batubara : 5\% Pellet sampah (seperti PLTU Jeranjang, PLTU Andrea Palladio Italia dan PLTU Donghae Korea Selatan), maka 5\% dari $20 \mathrm{t} / \mathrm{h}$ adalah $1 \mathrm{t} / \mathrm{h}$ Pellet sampah. Jadi, kebutuhan Pellet sampahnya adalah 3 ton per hari.

\section{KESIMPULAN}

Direct co-firing dengan menggunakan Pellet sampah Klungkung Bali layak diimplementasikan pada PLTU MSW dengan perbandingan 95\% batubara dan 5\% Pellet sampah, dengan parameter operasi, emisi, serta potensi korosi dalam kondisi aman (tidak ada masalah yang signifikan).

Direct co-firing dengan menggunakan Pellet sampah Klungkung Bali layakdiimplementasikan pada PLTU MSW, dengan nilai internal strategy factor analysis (IFAS) 3,03 atau atau dibulatkan menjadi 3 (kuat) dan nilai eksternal strategy factor analysis (EFAS) 2,6 atau dibulatkan menjadi 3 (kuat).

\section{UCAPAN TERIMAKASIH}

Penulis mengucapkan terima kasih kepada PT Makmur Sejahtera Wisesa subsidiary of PT Adaro Power atas dukungan pada penelitian ini.

\section{DAFTAR PUSTAKA}

[1] Badan Pusat Statistik. 2017. Statistik Lingkungan Hidup Indonesia 2017. Katalog : 3305001.

[2] Baskakov, A. P. 2014. The prospect for incineration of municipal solid waste in Russia in order to produce heat and electric power. Thermal Engineering 61. 265-273. Yekaterinburg.

[3] Ecoprogetto, V. 2016. Tracciabilitả $e$ certificazione del recupero di RIFUTO URBANO RESIDUO proveniente dalle raccolte differenziatte, Bureau Veritas Certification, Milan.

[4] Fantini, V. dan A. Cavalierre. 2012. Boiler corrosion monitoring of Fusina co-firing power plant. DEBCO Project - Final Conference. Brussel.

[5] Gendebien, A., A. Leavens, et al., 2003. Refuse Derived Fuel, Current Practice and Perspectives. European Commission Directorate General Environment.

[6] Kementerian Pekerja Umum dan Perumahan Rakyat. 2016. Indonesia Bebas Sampah 2020. Buletin Cipta Karya Edisi 02. Jakarta.

[7] Kim, D. W., J. M. Lee, et al., 2010. Co-combustion of refuse derived fuel with anthracites in a CFB boiler. Proceedings of the 20th International Conference on Fluidized Bed Combustion, Springer. 262-270. Beijing.

[8] Kupka, T. T., Mancini, et al., 2008. Investigation of ash deposit formation during co-firing of coal with sewage sludge, saw-dust and refuse derived fuel. Fuel 87. 28242837. Clausthal-Zellerfeld.

[9] Legino, S. 2018. Listrik Kerakyatan : Opsi untuk melistriki seluruh Negeri dengan Energi Terbarukan. Modul Seminar dan Pelatihan PT Hariff Daya Tunggal Engineering, Bandung

[10] Pronobis, M. 2006. The influence of biomass co-combustion on boiler fouling and efficiency. Fuel 85. 474480. Silesian.

[11] Rangkuti, F. 2000. Analisis SWOT Teknik Membedah Kasus Bisnis. Jakarta: Gramedia Pustaka Utama.

[12] Sikumbang, H., R. Cahyaningtyas, et al., 2018. Simulasi Pembuatan dan Pemanfaatan Briket pada Listrik Kerakyatan. Jurnal PETIR, Vol. 11, No. 1. Jakarta.

[13] Sistem Informasi Pengelolaan Sampah Nasional. 2019, diakses 
dari www.sipsn.menlhk.go.id, pada 23 Februari 2019.

[14] STT-PLN. 2019. Peranan Warga untuk Meningkatkan Efisiensi Energi dan Pengembangan Energi Terbarukan. Forum Energi DKI. Jakarta.

[15] Subawa, I. 2019. Pertama di Indonesia, PT Indonesia Power Melakukukan Uji Coba Co-firing untuk Kurangi Penggunaan Batubara di PLTU, diakses dari www.indonesiapower.co.id, pada 30 April 2019.

[16] Vekemans, O dan J. Chaouki. 2016. Municipal Solid Waste Cofiring in Coal Power Plants: Combustion Performance. Book Developments in Combustion Technology Chapter 5. Montreal.

[17] Warlina, L. E. Noor, et al., 2008. Kebijakan Manajemen Lingkungan untuk Emisi Dioksin/Furan yang
Bersumber dari Industri Logam. Jakarta: Jurnal Organisasi dan Manajemen. Vol. 4, No. 2 : 63-72.

[18] Wei, X., Y. Wang, et al., 2009. Release of sulfur and chlorine during cofiring RDF and coal in an internally circulating fluidized bed. Energy \& Fuels 23. 1390-1397. Beijing.

[19] Winaya, N. S. dan I. B. Agung. 2010. Co-firing Sistem Fluidized Bed Berbahan Bakar Batubara dan Ampas Tebu. Jurnal Ilmiah Teknik Mesin Cakra. Vol. 4, No. 2 : 180188. Bali.

[20] Zotto, D., A. Tallini, et al., 2015. Energy enhancement of solid recovered fuel within systems of conventional thermal power generation. Energy Procedia 81. 319-338. Roma.

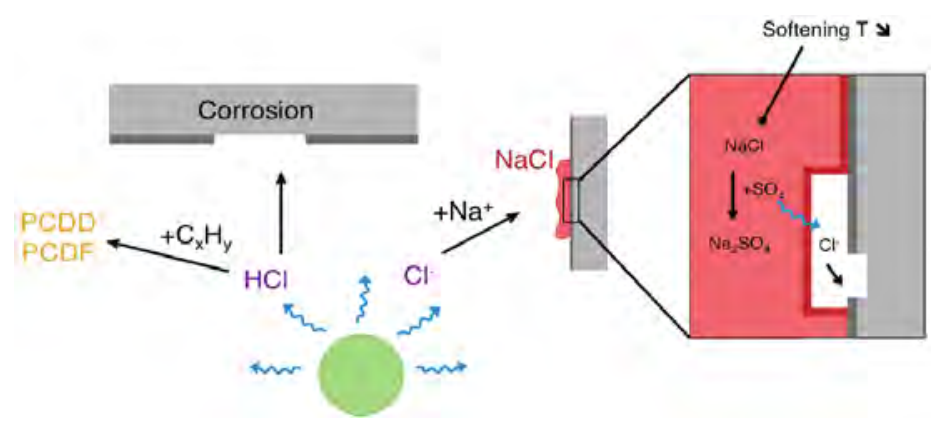

Gambar 1. Ilustrasi perilaku chlorine pada proses pembakaran [16]

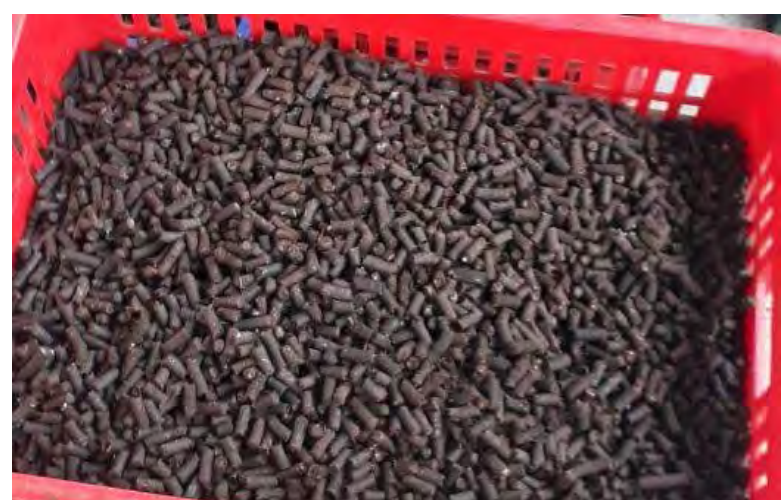

Gambar 2. Pellet sampah hasil peuyeumisasi [14]

Tabel 1. Pellet sampah Bali vs Pellet sampah Korea Selatan vs Pellet sampah Italia 


\begin{tabular}{|c|c|c|c|c|}
\hline Parameter & Unit (Basis) & $\begin{array}{c}\text { Pellet Sampah } \\
\text { Bali }\end{array}$ & $\begin{array}{l}\text { Pellet Sampah } \\
\text { Korea Selatan }\end{array}$ & $\begin{array}{c}\text { Pellet Sampah } \\
\text { Italia }\end{array}$ \\
\hline \multicolumn{5}{|c|}{ Proximate Analysis } \\
\hline $\begin{array}{l}\text { Net calorific } \\
\text { value (NCV) }\end{array}$ & $\mathrm{Kcal} / \mathrm{kg}$ (ar) & 2767 & 4182 & 4349 \\
\hline Moisture & \multirow{4}{*}{$\%$} & 6,6 & 1,58 & 7,35 \\
\hline Ash & & 35 & 31,03 & 16,95 \\
\hline Fixed carbon & & 11,6 & 5,11 & $*_{-}$ \\
\hline Volatile matter & & 46,8 & 62,28 & - \\
\hline \multicolumn{5}{|c|}{ Ultimate Analysis } \\
\hline Karbon & \multirow{6}{*}{$\%(a r)$} & 30,6 & 39,15 & - \\
\hline Hidrogen & & 4,24 & 5,13 & - \\
\hline Oksigen & & 17,8 & 24,01 & - \\
\hline Nitrogen & & 1,6 & 0,11 & - \\
\hline Sulfur & & 0,18 & 0,08 & - \\
\hline$A s h$ & & 33 & 31,52 & - \\
\hline Klorin & $\%(d)$ & 1,1 & 0,8 & 0,92 \\
\hline Merkuri & mg/MJ (ar) & - & - & 0,024 \\
\hline
\end{tabular}

Keterangan : $\mathrm{ar}=$ as-received $; \mathrm{d}=d r y$

* data tidak ditemukan

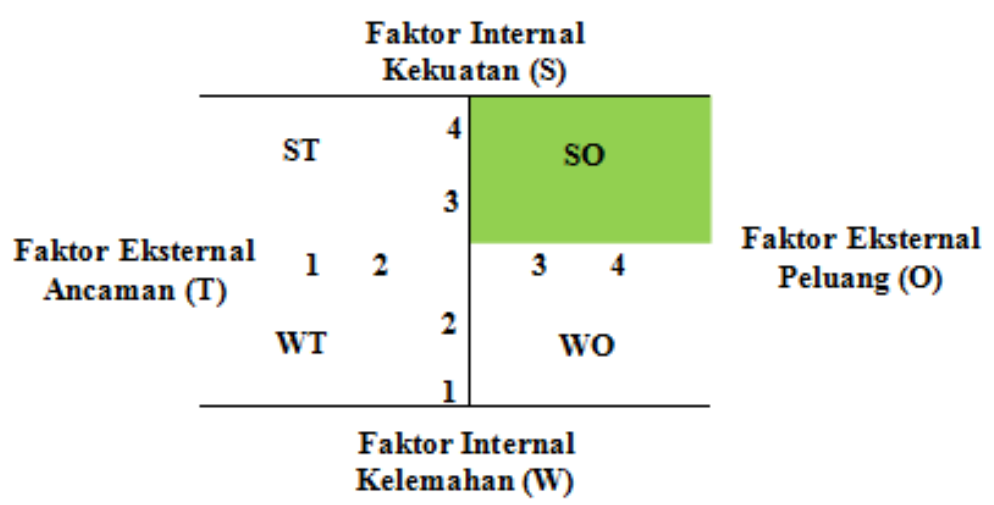

Gambar 3. Diagram SWOT

Tabel 2. Internal Strategy Factor Analysis (IFAS)

\begin{tabular}{|c|c|c|c|c|}
\hline No. & IFAS & Rating & Bobot & Jumlah \\
\hline \multicolumn{5}{|c|}{ Strength (Kekuatan) } \\
\hline 1. & $\begin{array}{l}\text { Mendukung program pemerintah dalam mengurangi } \\
\text { konsumsi energi fosil, seperti batubara }\end{array}$ & 3 & 0,16 & 0,48 \\
\hline 2. & Mendukung program pemerintah "waste to energy" & 3 & 0,16 & 0,48 \\
\hline 3. & $\begin{array}{l}\text { Mendukung program pemerintah perihal lingkungan } \\
\text { hidup }\end{array}$ & 3 & 0,16 & 0,48 \\
\hline 4. & $\begin{array}{l}\text { Menurunkan emisi GHG (Greenhouse Gas), yaitu } \mathrm{CO}_{2} \\
\text { pada PLTU dan } \mathrm{CH}_{4} \text { dari penimbunan limbah pada } \\
\text { TPA }\end{array}$ & 3 & 0,15 & 0,45 \\
\hline 5. & $\begin{array}{l}\text { Harga Pellet sampah (Rp } 400.000 \text { per metrik ton) lebih } \\
\text { murah dari batubara (Rp } 570.000 \text { per metrik ton) }\end{array}$ & 3 & 0,14 & 0,42 \\
\hline \multicolumn{5}{|c|}{ Weakness (Kelemahan) } \\
\hline 1 & $\begin{array}{l}\text { Belum cukup informasi tentang pengaruh co-firing } \\
\text { Pellet sampah dan batubara di PLTU }\end{array}$ & 3 & 0,12 & 0,36 \\
\hline
\end{tabular}




\begin{tabular}{|c|l|c|c|c|}
\hline 2 & $\begin{array}{l}\text { Mempengaruhi kandungan } \text { ash yang akan diambil oleh } \\
\text { pabrik semen }\end{array}$ & 3 & 0,12 & 0,36 \\
\hline \multicolumn{2}{|c|}{ TOTAL } & $\mathbf{1}$ & $\mathbf{3 , 0 3}$ \\
\hline
\end{tabular}

Tabel 3. Eksternal Strategy Factor Analysis (EFAS)

\begin{tabular}{|c|l|c|c|c|}
\hline No. & \multicolumn{1}{|c|}{ EFAS } & Rating & Bobot & Jumlah \\
\hline \multicolumn{3}{|c|}{ Opportunities (Peluang) } & 0,2 & 0,6 \\
\hline 1 & $\begin{array}{l}\text { Membuka lapangan kerja baru bagi masyarakat sekitar } \\
\text { TPS untuk mengolah sampah menjadi Pellet sampah } \\
\text { sebagai bahan bakar }\end{array}$ & 3 & 0,2 & 0,6 \\
\hline 2 & $\begin{array}{l}\text { Memaksimalkan sumber energi lokal berupa sampah } \\
\text { kota (municipal solid waste) }\end{array}$ & 3 & 0,2 & 0,6 \\
\hline 3 & $\begin{array}{l}\text { Mengubah habit \& mindset masyarakat untuk selektif } \\
\text { dalam melakukan pemilahan sampah }\end{array}$ & 2 & 0,13 & 0,26 \\
\hline 1 & $\begin{array}{l}\text { Kandungan klorin dan alkali pada Pellet sampah } \\
\text { meningkatkan risiko korosi }\end{array}$ & 2 & 0,13 & 0,26 \\
\hline 2 & $\begin{array}{l}\text { Kandungan klorin pada Pellet sampah meningkatkan } \\
\text { risiko peningkatan emisi dioksin dan furan }\end{array}$ & 2 & 0,14 & 0,28 \\
\hline 3 & $\begin{array}{l}\text { Sustainability dari program direct } \text { co-firing, karena } \\
\text { permasalahan jumlah dan kapasitas peralatan } \\
\text { pengolahan sampah yang kurang (keramba bambu, } \\
\text { mesin pencacah, mesin pencetak Pellet dll.) } \\
\text { dibandingkan jumlah sampah yang masuk, sehingga } \\
\text { tidak ada kasus sampah membeludak dan tertumpuk } \\
\text { begitu saja }\end{array}$ & 2 & $\mathbf{1}$ & $\mathbf{2 , 6}$ \\
\hline
\end{tabular}

